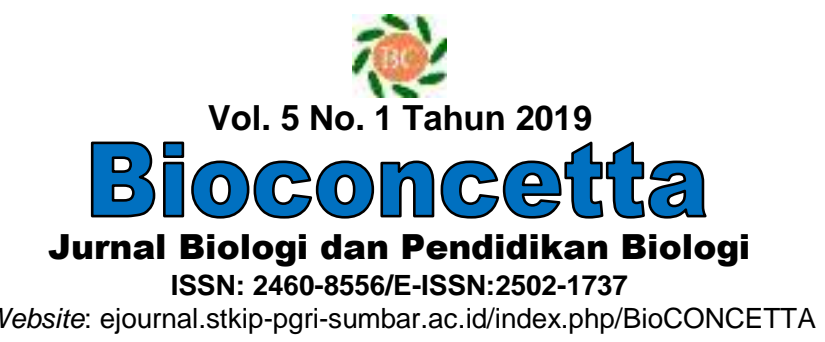

\title{
Implementasi Pembelajaran Mikrobiologi dan Parasitologi pada Materi Virus Terhadap Hasil Belajar Mahasiswa
}

Rahmi Septia Sari

Akademi Perekam Informasi Kesehatan (APIKES) Iris Padang

Jl. Gajah Mada No. 23 Padang, Sumatera Barat, Indonesia

Email: rahmiseptiasari88@gmail.com

Info Artikel

Sejarah Artikel

Diterima:

13 Juli 2019

Disetujui:

18 Juli 219

Dipublikasikan:

31 Agustus 2019

Kata Kunci:

Pembelajaran,

Mikrobiologi,

Parasitologi, Materi.

Keywords:

Learning,

Microbiology,

Parasitology,

Materials.

\begin{abstract}
Abstrak
Penelitian ini bertujuan untuk mengetahui implementasi pembelajaran mikrobiologi dan parasitologi pada materi Virus di Apikes Iris Padangyang meliputi perancangan, implementasi dan penilaian hasil pembelajaran. Informan dalam penelitian ini adalah dosen Mikrobiologi dan Parasitologi sertaapresiasi mahasiswa Apikes Iris Padang. Jenis penelitian ini adalah penelitian deskriptif dengan pendekatan kualitatif dengan cara melihat hasil tes. Berdasarkan temuan hasil penelitian dapat teramati bahwa dosen tidak merencanakan pembelajaran secara kontekstual dengan konteks tempat atau ruang kelas dimana pembelajaran dilaksanakan, Dosen yang menerapkan pembelajaran belum efektif dan efisien karena dosen belum dapat memanfaatkan waktu secara efektif, dosen belum dapat menetapkan dan memilih media pembelajaran sesuai dengan kriteria bahan ajar dan pembelajaran belum efektif karena terbatasnya jumlah dan kualitas peralatan laboratorium. Dosen melakukan penilaian hasil belajar mahasiswa untuk kuis dengan mekanisme dan prosedur yang belum tepat.
\end{abstract}

\begin{abstract}
This aims of research is to find out the implementationlearning of microbiology and parasitology at the material Virus in the Apikes Iris Padang which includes the design, implementation and assessment of learning. Informant's research is lecture of Microbiology and Parasitology and Students Apikes Iris Padang. This type of research is descriptive research with a qualitative approach. Based on the findings, we can conclude that Lecturers are not planning independently contextual learning context-sensitive places or classrooms where learning implementation. Lecturer implementing the learning has not been effective and efficient due tolecturers have not been able to utilize time effectively, lecturers have not been able to establish and selecting instructional media appropriate in accordance with the criteria of the study material the learning has not been effectivedue to the limited number and quality of laboratory equipment. Lecturer already conducted an assessment of student learning outcomes for the quiz with the mechanisms and procedures that have not been right.
\end{abstract}




\section{PENDAHULUAN}

Pemerintah

mempunyai komitmen yang kuat dalam mengembangkan sumber daya manusia (SDM) guna mendukung upayapembangunan nasional.

Pengembangan SDM yang bermutu dapat dicapai jika didukung oleh sistem pendidikan Nasional yang kompeten. Dalam UndangundangSistem Pendidikan Nasional No. 20 tahun 2003 Pasal 1 ayat 1 tercantum bahwa, pendidikan adalah usaha sadar terencana untuk mewujudkan suasana belajar dan proses pembelajaran agar mahasiswa secara aktif mengembangkan potensidirinya untuk memiliki kekuatan spiritual keagamaan, pengendalian diri, kepribadian, kecerdasan, akhlak mulia serta keterampilan yang diperlukan dirinya, masyarakat, bangsa dan Negara. Banyak usaha yang telah dilakukan pemerintah untuk meningkatkan mutu pendidikan seperti perbaikan kurikulum, sumber belajar, penataran guru dan perbaikan sarana dan prasarana belajar.

Namun harus dipahami, pendidikan yang dapat mendukung pembangunan adalah pendidikan yang mampu mengembangkan potensi mahasiswa, sehingga yang bersangkutan mampu menghadapi dan memecahkan masalah kehidupan yang dihadapinya. Salah satunya melalui pendidikan formal.

Pendidikan formal merupakan proses pembelajaran yang melibatkan berbagai komponen diantaranya dosen, mahasiswa, tujuan pembelajaran,bahan pembelajaran, metode, media dan situasi lingkungan belajar. Sanjaya (2015) enyatakan bahwa proses pembelajaran merupakan proses yang didalamnya terkandung kegiatan interaksi dan komunikasi timbal balik antara guru dan siswa yang berlangsung dalam situasi edukatif untuk mencapai tujuan pembelajaran. Selanjutnya ditinjau dari mahasiswa, masih kurangnya kemauan dan motivasi belajar merupakan masalah yang sering terjadi pada proses perkuliahan serta masih terlihat kurangnya penguasaan konsep. Berdasarkan informasi dari dosen mikrobiologi dan parasitologi Apikes Iris, salah satu materi yang hasil belajarnya rendah yaitu materi virus, hal ini terlihat dari persentase ketuntasan belajar mahasiswa yang berkisar antara 20\%-90\% .

Rendahnya hasil belajar pada materi virus disebabkan karena proses pembelajaran yang kurang efektif, kurangnya motivasi mahasiswa dalam belajar, sarana dan prasarana yang belum lengkap, metode dan media pembelajaran yang dipakai dosen belum profesionalserta keterbatasan sumber belajar lainnya.

$\begin{array}{llr}\begin{array}{l}\text { Tenaga } \\ \text { profesional }\end{array} & \text { pengajar hendaknya } & \text { yang } \\ \text { mampu }\end{array}$
tanggungjawab sebagai dosen terhadap mahasiswa, guru kepada siswa, orang tua, masyarakat, bangsa, negara dan agamanya. Hal ini menuntut tenaga pengajar agar lebih menyiapkan segala sesuatunya sebelum perkuliahan berlangsung. 
Sudjana (2017) berpendapat bahwa ada tiga hal pokok yang harus diperhatikan tenaga pengajar dalam melakukan proses perkuliahan. Pertama adalah tahap perencanaan proses pembelajaran, kedua adalah menggunakan atau pendekatan mengajar (alat peraga) dan tahap ketiga tahap evaluasi hasil belajar. Ketiga tahapan tersebut harus ditempuh pada setiap saat melaksanakan pembelajaran maupun perkuliahan. Satu tahap ditinggalkan, sebenarnya tidak dapat dikatakan proses pembelajaran. Hal tersebut juga terdapat pada Permendiknas No. 41 tahun 2007 tentang standar proses. Standar proses adalah standar nasional pendidikan yang berkaitan dengan pelaksanaan proses pembelajaran pada satuan pendidikan untuk mencapai kompetensi lulusan yang meliputi perencanaan, pelaksanaan dan penilaian pembelajaran. Berdasarkan keterangan di atas, Saya melakukan penelitian ditingkat perguruan tinggi dengan judul "Implementasi pembelajaran mikrobiologi dan parasitologi pada materi virus terhadap hasil belajar mahasiswa Apikes Iris".

\section{BAHAN DAN METODE}

Penelitian yang dilakukan ini merupakan penelitian deskriptif dengan pendekatan kualitatif. Penelitian kualitatif ini mengacu pada konsep Miles dan Huberman dalam Nurmay Elda (2014) yakni penelitian naturalistik kualitatif dan selama pengumpulan data, dilakukan analisis datadengan model siklus interaktif melalui serangkaian proses, reduksi data, penyajian data dan verifikasi data.Penelitian tentang implementasi pembelajaran mikrobiologi di Apikes Iris Padang adalah meneliti segala aktivitas pembelajaran pada materi virus yang meliputi pencanaan, proses, dan penilaian hasil pembelajaran pada materi virus.

Teknik dan alat pengumpulan data yang digunakan dalam penelitian ini adalah observasi,wawancara dan studi dokumentasi. Kegiatan observasi dalam penelitian ini dilakukan pengamatan langsung dengan Dosen Mikrobiologi dalam kegiatan pembelajaran. Wawancara dilakukan dengan dosen dan mahasiswa kelas A semester II TA 2015/2016 di Apikes Iris Padang.Berisi data verbal yang berbentuk tulisan. Studi dokumentasi yang dilakukan dalam penelitian ini untuk mengungkapkan data akurat yang bersifat administrasi seperti data geografis, struktur organisasi, struktur personalia, denah, kurikulum, silabus, perangkat perkuliahan yang ada di Apikes Iris.

Keabsahan data yang diperoleh di lapangan diperiksa dengan menggunakan teknik-teknik yang disarankan Lincoln dan Guba (1985) dalam Afrizal (2012) yakni dengan teknik keterpercayaan dan dapat dipertanggungjawabkan. Informan dalam penelitian ini melibatkan dosen yang mengampu matakuliah mikrobiologi dan parasitologi yaitu Ibu Dewi Oktavia, S.KM, Ibu Yanti Desnita Tasri, M.Kom selaku Direktur Apikes Iris, Ibu Selvi Zola Fenia, S.Psi, MM dan beberapa orang mahasiswa yang ikut diwawancarai 
untuk diminta keterangan mengenai Proses belajar mengajar pada matakuliah Mikrobiologi dan Parasitologi pada materi Virus. Teknik keterpercayaan dapat dilakukan oleh peneliti, yaitu, ketekunan pengamatan untuk menentukan ciri-ciri dan unsur-unsur dalam situasi yang benar-benar relevan dengan permasalahan, triangulasi merupakan teknik pemeriksaan data yang memanfaatkan sesuatu di luar data itu, dimana pengecekan derajat kepercayaan melalui beberapa sumber datadengan metode wawancara, dan yang terakhir adalah pemeriksaan teman sejawat melalui diskusi. Adapun teknik selanjutnya adalah dapat dipertanggungjawabkan dalam paradigma positivistik dan reabilitas. Penentuan dapat tidaknya hasil penelitian dibuat replikasi atau uji ulang, mengingat studi dengan paradigma positif memandang bahwa realita itu terkait langsung dengan konteks waktu, maka tidak mungkin untuk mengadakan replikasi hasil studi.

Teknik analisis data yang digunakan dalam penelitian ini mengaju kepada model interaktif yang dikemukakan oleh Miles dan Huberman (1992), Teknik tersebut dimulai dari proses Reduksi data yang merupakan suatu proses pemilihan, penyeleksian, penyederhanaan, pemusatan perhatian, dan mentransformasikan data mentah yang diperoleh dalam matriks catatan lapangan sebagai rangkuman data bersifat deskriptif. Selanjutnya Penyajian data dilakukan dengan menampilkan informasi yang didapat melalui kegiatan reduksi data. Informasi yang diperoleh baik melalui observasi maupun wawancara dihimpun diorganisasikan sesuai dengan fokus masalah yang diteliti, dan disusun data-data yang relevan, sehingga menjadi informasi yang dapat disimpulkan dan memiliki makna tertentu. Pada langkah verifikasi atau penarikan kesimpulan, peneliti masih dapat menerima masukan data dari peneliti lain, sampai pengumpulan data dinyatakan berakhir. Selanjutnya peneliti menggambarkan dan menjelaskan tentang aktivitas pembelajaran pada materi virus yang meliputi, perencanaan pembelajaran, proses pembelajaran serta penilaian hasil belajar pada materi virus.

\section{HASIL DAN PEMBAHASAN}

Berdasarkan hasil observasi, wawancara dengan Direktur Apikes Iris yaitu Ibu Yanti Desnita Tasri, M.Kom, Ibu Selvi Zola Fenia, S.Psi, MM, Ibu Dewi Oktavia, SKM serta beberapa mahasiswa yang mengikuti perkuliahan selaku informan dalam penelitian ini dan studi dokumentasi yang telah dilakukan peneliti, berikut ini dipaparkan hasil penelitian yang telah dilakukan; tentang profil Apikes Iris Padang, strukturorganisasi Apikes Iris Padang, keadaan dosen Apikes Iris Padang, keadaan Mahasiswa Apikes Iris Padang, kegiatan pembelajaran dan perkuliahan di Apikes Iris Padang.

Berdasarkan dokumentasi yang peneliti dapatkan, mahasiswa Apikes Iris pada tahun ajaran 2016/2017 
berjumlah 211 orang yang terdiri dari mahasiswa TA 2014/2015, mahasiswa TA 2015/2016 dan mahasiswa TA
2016/2017, jumlah mahasiswa dapat dilihat pada Tabel 3 berikut ini.

Tabel 3. Jumlah Mahasiswa Apikes Iris Padang Tahun Ajaran 2016/2017

\begin{tabular}{ccccc}
\hline No & Tahun Ajaran & Laki-Laki & Perempuan & Jumlah \\
\hline 1 & $2014 / 2015$ & 9 & 55 & 64 \\
2 & $2015 / 2016$ & 19 & 65 & 84 \\
3 & $2016 / 2017$ & 9 & 49 & 58 \\
& & Jumlah & & 206 \\
\hline
\end{tabular}

Sumber: Dokumen Apikes Iris Padang Tahun 2016/2017.

Mahasiswa yang ada di Apikes Iris Padang rata-rata berasal dari latar belakang pekerjaan orang tua yang berbeda, dokumentasi yang peneliti dapatkan maka pekerjaan orang tua mahasiswa dilihat pada Tabel 4.

Tabel 4. Persentase Pekerjaan Orangtua Mahasiswa TA. 2016/2017.

\begin{tabular}{ccc}
\hline No & Pekerjaan & Persentase \\
\hline 1 & Tani & $45 \%$ \\
2 & Pedagang & $20 \%$ \\
3 & PNS & $15 \%$ \\
4 & Swasta & $30 \%$ \\
\hline
\end{tabular}

Wawancara peneliti dengan informan 04 perwakilan mahasiswa tentang pekerjaan orang tua danmotivasi dari orang tua. Beliau menyatakan; Kedua orangtua saya berprofesi sebagai petani yang bekerja di kebun karet. Orangtua saya pergi ke kebun jam enam pagi dan pulang jam lima sore, Orangtua saya memotivasi saya belajar hanya dengan memberikan pesan di rumah menjelang berangkat ke tempat kuliah, setelah saya sampai di tempat kuliah saya belajar atas kemauan sendiri (21 September 2016).

Berdasarkan wawancara peneliti dengan informan 02 tentang kurikulum yang diterapkan di Apikes Iris Padang, hasil observasi dan wawancara yang telah ditriangulasi maka dapat disimpulkan bahwa kurikulum yang berlaku di Apikes Iris Padang adalah kurikulum KBK. beliau menyatakan bahwa kurikulum yang diterapkan di Apikes Iris Padang saat ini adalah kurikulum Berbasis Kompetensi (KBK). Kurikulum tersebut merupakan pedoman dosen dalam melaksanakan proses pembelajaran (21 September 2016). Dalam satu minggu terdiri dari 67 jam pelajaran, setiap hari proses pembelajaran dimulai jam 08.00 WIB sampai jam 16.00 WIB pengecualian untuk hari minggu (21 September 2016). Berdasarkan observasi dan wawancara yang telah ditriangulasi maka dapat disimpulkan bahwa kurikulum yang berlaku di Apikes Iris Padang adalah kurikulum Berbasis Kompetensi (KBK). 
Proses pembelajaran akan terlaksana dengan baik jika didukung oleh perencanaan dan persiapan dosen sebelum perkuliahan dimulai. Hal tersebut bermaksud jika perumusan dan penyusunan RPKPS dan SAP tidaksesuai maka akan berpengaruh kepada proses perkuliahan yang akan dilaksanakan oleh dosen. Sebab RPKPS dan SAP merupakan pedoman bagi dosen untuk menerapkan materi pelajaran.

Proses pembelajaran akan terlaksana dengan baik jika didukung oleh perencanaan dan persiapan dosen sebelum perkuliahan dimulai. Hal tersebut harus mengacu kepada semua kegiatan yang akan dilakukan dosen dalam mempersiapkan diri sebelum memulai dan melaksanakan pembelajaran. Persiapan yang harus dilakukan terlebih dahulu adalah menyusun Rancangan Program Kegiatan Pembelajaran Semester (RPKPS) dan satuan acara perkuliahan (SAP), karena menyusun RPKPS dan SAP tersebut mempunyai hubungan yang erat dengan proses perkuliahan di ruang kuliah. Hal tersebut bermaksud jika perumusan dan penyusunan RPKPS dan SAP tidak sesuai maka akan berpengaruh kepada proses perkuliahan yang akan dilaksanakan oleh dosen. Sebab RPKPS dan SAP merupakan pedoman bagi dosen untuk menerapkan materi pelajaran.

Dilakukan wawancara dengan informan 03 tentang keberadaan RPKPS perkuliahan mikrobiologi dan parasitologi, beliau menjawab RPKPS tersebut saya dapatkan dari teman sesama dosen mikrobiologi sebelumnya tanpa saya harus membuat kembali sehingga saya harus memahaminya terlebih dahulu sehingga persiapan saya sebelum proses pembelajaran belum efektif ( 25 September 2016).

Dari hasil wawancara di atas dapat terlihat dosen mikrobiologi dan parasitologi tidak memiliki RPKPS, hanya menggunakan RPKPS dari milik dosen sebelumnya. Untuk mempertegas informasi, peneliti melakukan triangulasi dari beberapa informan dan dokumentasi, maka ditarik kesimpulan bahwa dosen mikrobiologi hanya menggunakan RPKPS dari dosen sebelumnya. Menurut Permendiknas Nomor 41 Tahun 2007 menyatakan, dalam pelaksanaannya pengembangan silabus maupun Rencana Pembelajaran atau RPKPS dapat dilakukan oleh para guru maupun dosen secara mandiri atau berkelompok dalam sebuah forum atau lingkungan pendidikan formal lain. Jadi, sebaiknya setiap dosen secara mandiri atau berkelompok harus mengembangkan silabus atau RPKPS sesuai dengan yang dicantumkan dalam kurikulum KBK sehingga dosen dapat dikatakan professional dan melaksanakan Tridharma Perguruan Tinggi.

Pelaksanaan perkuliahan merupakan tahapan proses yang sangat komplek, salah satu faktor utama dalam perkuliahan yaitu mahasiswa. Berikut gambaran pelaksanaan perkuliahan mikrobiologi pada materi virus di Apikes Iris Padang.

Persyaratan pelaksanaan proses perkuliahan yang pertama adalah 
rombongan perkuliahan. Berdasarkan observasi di kelas A dan B, jumlah mahasiswa perkelasnya yaitu kelas A berjumlah 42 orang dan $B$ berjumlah 50 orang.

Beban kerja minimal dosen. Berdasarkan observasi beban kerja minimal dosen mikrobiologi yaitu 4 sks tatap muka dalam satu minggu. Hal tersebut harus sesuai dengan Permendiknas No. 14 tahun 2007, bahwa beban kerja dosen sekurangkurangnya 24 jam tatap muka dalam satu minggu. Beban kerja dosen mencakup kegiatan pokok yaitu merencanakan perkuliahan, melaksanakan perkuliahan, menilai hasil belajar, membimbing dan melatih mahasiswa serta melaksanakan tugas tambahan. Sebaiknya setiap dosen memiliki sekurang-kurangnya 12 jam tatap muka dalam satu minggu agar kegiatan pokok yang dimiliki dosen dapat terlaksana seperti yang seharusnya.

Buku teks pelajaran. Berdasarkan observasiyang peneliti lakukan rata-rata masiswa memiliki buku pegangan berupa diktat. Untuk mempertegas informasi yang didapat maka peneliti mewawancarai informan dengan ibu Dewi Oktavia, SKM tentang buku pegangan mahasiswa, beliau menyatakan: Buku pegangan yang digunakan mahasiswa masih terbatas berupa diktat dan belum ada buku ajar lain, Jumlah Diktat diberikan kepada masing-masing mahasiswa sebagai sumber belajar (25 September 2016). Dari wawancara pelaksanaan proses perkuliahan di atas dapat disimpulkan bahwa, jumlah diktat yang digunakan sudah cukup, tetapi sumber lain tidak ada digunakan sehingga informasi yang didapat sangat terbatas di lingkungan kampus.

Berdasarkan observasi dan wawancara serta diadakan triangulasi maka dapat disimpulkan: bahwa jumlah rombongan mahasiswa yang mengikuti perkuliahan agak padat dan menyebabkan kondisi yang tidak kondusif. Pada saat perkuliahan berlangsung ada beberapa mahasiswa yang tidak disiplin dan mengganggu proses perkuliahan. Buku sumber yang ada sangat terbatas sehingga mahasiswa kurang aktif untuk bertanya.

Pelaksanaan perkuliahan berlangsung dalam suasana tertentu, terdapat faktor-faktor yang saling berhubungan mulai dari tujuan perkuliahan, mahasiswa yang belajar, dosen yang mengajar, bahan yang diajarkan, metode perkuliahan, alat bantu mengajar, prosedur penilaian, dan situasi pengajaran. Dalam proses perkuliahan tersebut,semua faktor bergerak secara dinamis dalam suatu rangkaian yang terarah dalam rangka membawa para mahasiswa untuk mencapai tujuan pembelajaran. Pelaksanaan perkuliahan adalah operasionalisasi dari perencanaan perkuliahan, sehingga tidak lepas dari perencanaan perkuliahan yang sudah dibuat. Oleh karena itu dalam pelaksanaannya akan sangat tergantung bagaimana perencanaan perkuliahan sebagai operasionalisasi dari sebuah kurikulum. Selain itu, pelaksanaan perkuliahan juga meliputi 
kegiatan pendahuluan, kegiatan inti dan kegiatan penutup.

Sesuai dengan Permendiknas No. 14 tahun 2007, Penilaian dilakukan oleh dosen terhadap hasil pembelajaran untuk mengukur tingkat pencapaian kompetensi peserta didik, serta digunakan sebagai bahan penyusunan laporankemajuan hasil belajar, dan memperbaiki proses pembelajaran.Penilaian dilakukan secara konsisten, sistematik dan terprogram dengan menggunakan tes dan nontes dalam bentuk tertulis atau lisan, pengamatan kinerja, pengukuran sikap, penilaian hasil karya berupa tugas, proyek atau produk, portofolio, dan penilaian diri.

Penilaian hasil pembelajaran menggunakan standar penilaian pendidikan dan panduan penilaian kelompok mata kuliah. berdasarkan hasil observasi dapat disimpulkan bahwa rendahnya hasil belajar mahasiswa tidak hanya disebabkan oleh dosen, tetapi juga disebabkan olehkurang persiapan mahasiswa dalam pembelajaran, selain itu mahasiswa tidak memiliki minat dan keinginan untuk belajar. Faktor lain yang memiliki peranan penting dalam keberhasilan mahasiswa adalah orang tua. Kurangnya perhatian orangtua terhadap belajar mahasiswa merupakan penyebab utama rendahnya hasil belajar mahasiswa, sebab mahasiswa memiliki waktu yang lebih banyak untuk mengulang pelajaran di rumah atau di kos di banding dengan waktu belajar di kampus.

Dalam pelaksanaan implementtasi, banyak kendala yang terlihat dalam proses implementasi pembelajaran mikrobiologi dan parasitologi di Apikes pada materi Virus. Dari uraian temuan khusus sebelumnya terlihat, bahwa banyak kendala yang ditemui dalam mengimplementasikan pembelajaran mikrobiologi pada materi virus. Namun, secara garis besarnya kendalakendala tersebut dapat dikelompokkan atas beberapa kendala sebagai berikut: Kurangnya penguasaan kompetensi pedagogik dosen. Kendala ini diindikasikan oleh temuan, yaitu; dosen belum menyusun RPKPS, SAP yang sesuai dengan konteks dan situasi kampus dimana proses pembelajaran berlangsung; dosen belum memahami pelaksanaan dokumen perangkat pembelajaran, karena dokumen tersebut bukan hasil kerja dosen yang bersangkutan; dosen belum mampu memanfaatkan waktu secara efektif; dosen belum mampu memberi media pembelajaran yang tepat. Untuk mengatasi kendala tersebut perlu dilakukan pelatihan intensif tentang pengolahan pembelajaran dan pelatihan analisis konteks kampus. Pelatihan pengolahan pembelajaran meliputi pemahaman wawasan landasan kependidikan, pemahaman terhadap mahasiswa, pengembangan RPKPS, perancangan SAP, proses pembelajaran yang mendidik, memanfaatkan teknologi pembelajaran, penilaian hasil belajar dan pengembangan mahasiswa untuk mengaktualisasikan berbagai potensi yang dimiliki.

Analisis konteks kampus yang dimaksud berkaitan dengan Standar 
Nasional Pendidikan yang tertuangdalam Peraturan Pemerintah No. 18 tahun 2007, yakni standar kompetensi kelulusan, standar isi, standar proses, standar pendidikan dan tenaga kependidikan, standar sarana dan prasarana, standar pengolahan, standar pembiayaan dan standar penilaian. Jadi dapat disimpulkan dalam menyusun perangkat pembelajaran kita harus berpedoman kepada hasil analisis konteks kampus.

\section{SIMPULAN}

Berdasarkan hasil temuan penelitian dapat disimpulkan bahwa dosen tidak menyusun pembelajaran yang kontekstual, belum melaksanakan pembelajaran yang efektif dan efisien, belum mampu menetapkan dan memilih media pembelajaran yang tepat guna. Dosen telah melaksanakan penilaian hasil pembelajaran mahasiswa, namun mekanisme dan prosedur yang terapkan belum tepat.

Berdasarkan hasil observasi, wawancara dan studi dokumentasi faktor yang menjadi penyebab kurangnya pemahaman mahasiswa yaitu: Metode pembelajaran yang diterapkan masih kurang tepat, Kurang efisiennya pemanfaatan waktu oleh dosen, Dosen belum menguasai materi dengan baik, Kurangnya niat, minat dan keinginan mahasiswa untuk belajar, Kurangnya jumlah buku pegangan mahasiswa, dan Kurangnya motivasi dari orangtua terhadap belajar mahasiswa.
DAFTAR PUSTAKA

Afrizal. 2012. "Implementasi

Kurikulum SMK Negeri 1

Padang pada Pembelajaran Produktif Teknik Audio Video".

Tesis tidak diterbitkan. Padang:

Universitas Negeri Padang.

Desi Kurniawati. 2016. Penerapan Model Pembelajaran Inkuiri terbimbing LKS untuk meningkatkan proses Sains dan prestasi belajar. Jurnal Pendidikan Kimia. Jakarta: Universitas Negeri Sebelas Maret.

Depdiknas.2013. Undang-undang Republik Indonesia Nomor 32, Tahun 2013 tentang Standar Nasional Pendidikan. Jakarta: Menteri Pendidikan Nasional.

2017. Revisi Peraturan Pemerintah Nomor 19, Tahun 2005. Tentang perubahan kedua PP mengenai Standar Nasional Pendidikan.

2016. Peraturan Menteri Pendidikan Nasional Republik Indonesia Nomor 23 Tahun 2016 Tentang Standar Penilaian Pendidikan. Jakarta: Menteri Pendidikan Nasional.

. 2016. Peraturan Menteri Pendidikan Nasional Republik Indonesia Nomor 22 Tahun 2016 Tentang Standar Proses. Jakarta: Badan Standar Nasional Pendidikan.

Emzir. 2018. Metodologi Penelitian Kualitatit (Analisis Data). Jakarta: RajaGrafindo Persada.

Ernawati. 2016. Penerapan Model Pembelajaran Kooperatif Tipe Student Teams Achievement Division Untuk Meningkatkan Motivasi, Aktivitas dan Hasil 
Belajar Siswa Kelas X2 SMAN 1 Sungai Geringging Kabupaten Padang Pariaman. Jurnal Bioconcetta. 2 (1) 2016.

Megahati RRP. 2016. Aktivitas dan Hasil Belajar Siswa Dengan Menerapkan Pola U dan Media CD Dalam Proses Pembelajaran Biologi Kelas IX di SMP Negeri 35 Padang. Jurnal Bioconcetta. 2 (1) 2016.

Megahati RRP. 2016. Strategi Belajar Aktif Tipe Every One is a Teacher Here (ETH) Terhadap hasil belajar Siswa Kelas XI IA SMAN 5 Solok Selatan. Jurnal Bioconcetta. 2 (2). 2016

Nursyahra, N. 2016. Pengaruh Penerapan Pendekatan Saintifik dengan menggunakan strategi Pembelajaran Active Learning Tipe Guided Note Taking Terhadap Hasil Belajar Biologi
Siswa di SMA 15 Padang Jurnal Bioconcetta. 2 (2) 2016.

Nurmay EF. 2014. Implementasi Pembelajaran Biologi Pada Materi Protista Kelas X di SMA Negeri 2 Solok Selatan. Tesis tid diterbitkan. Padang: Universitas Negeri Padang.

Sanjaya, W. 2015. Perencanaan dan Desain System Pembelajaran. Jakarta: Kencana.

Sudjana, N. 2017. Penilaian Hasil Proses Belajar Mengajar cetakan ke 21. Bandung: PT. Remaja Rosdakarya.

Tran. V. 2014. The Effects of Cooperative Learning on The Academic Achievement and Knowledge Retention: International Journal of Higher Education. $3 \quad$ (2) 2014. Doi:10.5430/ijhe.v3n2p131 